Article

\title{
One-pot synthesis of ordered mesoporous Cu-KIT-6 and its improved catalytic behavior for the epoxidation of styrene: Effects of the $\mathrm{pH}$ value of the initial gel
}

\author{
Baitao Li*, Xin Luo, Jing Huang, Xiujun Wang, Zhenxing Liang\# \\ Key Laboratory of Fuel Cell Technology of Guangdong Province, School of Chemistry and Chemical Engineering, South China University of Technology, \\ Guangzhou 510640, Guangdong, China
}

\section{A R T I C L E I N F O}

\section{Article history:}

Received 12 November 2016

Accepted 20 December 2016

Published 5 March 2017

\section{Keywords:}

Mesoporous material

KIT-6

Styrene epoxidation

pH-adjusting

\begin{abstract}
A B S T R A C T
The heterogeneously copper-catalyzed oxidative cleavage of styrene was studied using copper-doped mesoporous KIT-6 (Cu-KIT-6x) prepared via pH adjustment (where $x$ is the pH: 1.43 , $2.27,3.78,3.97,4.24$ or 6.62 ). Variations in the catalyst structure and morphology with $\mathrm{pH}$ values were characterized by X-ray power diffraction, nitrogen adsorption-desorption analysis, transmission electron microscopy and X-ray photoelectron spectroscopy. As the $\mathrm{pH}$ value applied during the initial synthesis, the resulting Cu-KIT- $6_{x}$ exhibited different structural, textural and surface characteristics, especially in terms of specific copper species and copper content. At a pH value of 3.78, approximately $4.6 \mathrm{wt} \%$ copper(II) was successfully incorporated into the framework of the initial KIT-6, in the form of - $\mathrm{Cu}-\mathrm{O}-\mathrm{Si}$ - groups. The catalytic performance of each catalyst was evaluated by following the epoxidation of styrene, employing tert-butyl hydroperoxide as the oxidant and $\mathrm{CH}_{3} \mathrm{CN}$ as the solvent. A significant styrene conversion of $43.5 \%$ with $86.6 \%$ selectivity for the desired styrene epoxide was obtained over the Cu-KIT- $6_{3.78}$. A higher $\mathrm{Cu}$ content, an ordered cubic Ia3d mesoporous architecture and various specific textural characteristics all combined to endow the Cu-KIT-63.78 with high catalytic activity and good stability.
\end{abstract}

(C) 2017, Dalian Institute of Chemical Physics, Chinese Academy of Sciences. Published by Elsevier B.V. All rights reserved.

\section{Introduction}

The epoxidation of styrene is an extremely important industrial process, because the resulting styrene oxide (SO) is used in the manufacture of epoxy resins, paints, surfactants and pharmaceuticals. Despite this, the electrophilic addition of an oxidant to the styrene double bond is one of the most challenging steps in oxidation catalysis. Over the past several decades, considerable efforts has been devoted to designing appropriate and effective catalysts for the epoxidation of styrene [1]. Homogeneous catalysts, including polyoxometalate salts [2] and transition metals coordinated with porphyrins $[3,4]$ or salen [5], have been used to improve the conversion of olefins. However, these catalysts are difficult to separate from the product mixture and impossible to recycle. Thus, the immobilization of catalytically active metals on alumina [6], zeolites [7] or silica $[8,9]$ as heterogeneous catalysts would be useful.

KIT-6, developed by the Korea Advanced Institute of Science

\footnotetext{
* Corresponding author. Tel/Fax: +86-20-87112943; E-mail: btli@scut.edu.cn

\# Corresponding author. Tel/Fax: +86-20-87113584; E-mail: zliang@scut.edu.cn

This work was supported by Guangdong Science and Technology Planning Project (2015A020216002), Guangdong Natural Science Foundation (2014A030313259), and the National Natural Science Foundation of China (21543014, 21173086, U1301245).

DOI: 10.1016/S1872-2067(17)62767-0 | http://www.sciencedirect.com/science/journal/18722067 | Chin. J. Catal., Vol. 38, No. 3, March 2017
} 
and Technology, is a cubic Ia3d mesoporous silica with a bi-continuous structure, tunable pores, thick pore walls and high hydrothermal stability $[10,11]$. Unlike the two dimensional (2D) pore arrays in MCM-41 and SBA-15, KIT-6 incorporates unique $3 \mathrm{D}$ interpenetrating channels that facilitate the direct and open access of guest molecules without pore blockage. Thus, KIT-6 shows significant promise as a support for large molecule conversion reactions. Recently, numerous transition metals (such as $\mathrm{V}$ [12], Fe [13], Ni [14] and $\mathrm{Ti}$ [15]) have been anchored on KIT- 6 to catalyze organic reactions, including styrene epoxidation, methylcyclopentane conversion, fuel desulfurization and photocatalytic reduction.

So-called direct synthesis [16-19] is the main route to incorporating heteroatoms into the framework of mesoporous silicas. This process is time-efficient and simple, although only a small fraction of the metal in the initial synthetic system can be incorporated into the template matrix without reducing the structural periodicity. This is because the metal precursors are typically highly soluble and are primarily present in the synthesis solution as cations under highly acidic conditions, which reduces the formation of $-\mathrm{O}-\mathrm{M}-\mathrm{O}-\mathrm{Si}-\mathrm{O}-$ bonds (where $\mathrm{M}$ is the metal) during the condensation process. Several strategies have been developed to mitigate the difficulties associated with heteroatom grafting in acidic media. Xiao and co-workers [20] reported that $\mathrm{Al}^{3+}$ and $\mathrm{Ti}^{4+}$ can be substituted into SBA-15 at a $\mathrm{pH}$ of 7.5 using their so-called $\mathrm{pH}$ adjustment method, and that the finished products display highly ordered mesopores with large surface areas and uniform pore diameter distributions. Subsequently, Fe- [21], Cr- [22], Sn- [23], Ag- [24] and Niloaded [25] mesoporous SBA-15 materials were synthesized at $\mathrm{pH}$ values above 2 . Inspired by this method, some groups incorporated $\mathrm{Ga}$ [26] and $\mathrm{Cu}$ [27] into silica frameworks in dilute acids. These heteroatom-containing mesoporous silicas were found to be effective catalysts for styrene oxidation. As an example, La-doped KIT-6 (with a La in Si mole fraction of 0.02) synthesized at a pH of 8 yielded a styrene conversion of $20.6 \%$ and a selectivity for benzaldehyde of $74.6 \%$ during the oxidation of styrene with hydrogen peroxide [28]. Similarly, our research group determined an optimal $\mathrm{pH}$ value of 7.5 for the introduction of Co into the framework of SBA-15, resulting in a styrene conversion of $22 \%$ and a benzaldehyde selectivity of $92 \%$ in the same reaction process [29].

Copper oxide, a simple and inexpensive transition metal oxide, exhibits excellent catalytic activity for styrene epoxidation due to its high selectivity for SO [30-33]. However, there have been few reports of the addition of $\mathrm{Cu}$ to KIT- 6 by the $\mathrm{pH}$ adjustment method, and the effects of $\mathrm{pH}$ on the associated variations in structure and morphology remain unknown. A better understanding of the impact of structural properties on catalytic applications would enable the design of more efficient Cu-KIT-6 catalysts. In the present work, mesoporous Cu-KIT-6 materials were prepared using the $\mathrm{pH}$ adjustment method (with pH values from 1.43 to 6.62). The results demonstrate that the formation of different $\mathrm{Cu}$ species in the KIT- 6 is very sensitive to the $\mathrm{pH}$ value. A detailed characterization and discussion of the varying catalytic behavior during the epoxidation of styrene are provided herein.

\section{Experimental}

\subsection{Materials}

Pluronic P123 (poly(ethylene oxide)-poly(propylene oxide)poly(ethylene oxide) triblock copolymer, $\mathrm{EO}_{20} \mathrm{PO}_{70} \mathrm{EO}_{20}$, molecular weight $=5800$, Aldrich) was used as a structure-directing agent. $\mathrm{Cu}\left(\mathrm{NO}_{3}\right)_{2} \cdot 2.5 \mathrm{H}_{2} \mathrm{O}$ (Alfa Aesar) was employed as the $\mathrm{Cu}$ precursor. $n$-Butanol $(n$-BuOH), ethyl silicate (TEOS), concentrated $\mathrm{HCl}$ (37.0 wt\%), $\mathrm{NaOH}$ and $\mathrm{CH}_{3} \mathrm{CN}$ used in the synthesis as well as in catalytic experiments were all analytical reagent grade. Styrene (99.5\%) and tert-butyl hydroperoxide (TBHP, $70 \mathrm{wt} \%$ aqueous solution) were supplied by Alfa Aesar. All chemicals were used as received without further purification.

\subsection{Preparation of CU-KIT-6 mesoporous materials}

Ordered mesoporous Cu-KIT- 6 was synthesized via the $\mathrm{pH}$ adjustment method. Briefly, $2.50 \mathrm{~g}$ of Pluronic P123 was added to $90 \mathrm{~g}$ of distilled water and $4.9 \mathrm{~g}$ of $\mathrm{HCl}$ with stirring at room temperature. After the P123 was completely dissolved, $2.5 \mathrm{~g}$ of $n$-BuOH was added to the solution and the mixture was allowed to stir for $1 \mathrm{~h}$. Subsequently, $5.4 \mathrm{~g}$ of TEOS was added slowly in a dropwise manner and the solution was stirred for another 2 $h$, followed by the dropwise addition of a defined amount of $\mathrm{NaOH}$ solution $(10 \mathrm{~mol} / \mathrm{L})$ to adjust the $\mathrm{pH}$ of the mixture (Table 1). Following this, $1.45 \mathrm{~g}$ of solid $\mathrm{Cu}\left(\mathrm{NO}_{3}\right)_{2} \cdot 2 \cdot 5 \mathrm{H}_{2} \mathrm{O}$ was added to the solution and the resulting light green mixture was stirred vigorously for $22 \mathrm{~h}$. In the final step, the mixture was transferred into a polypropylene bottle that was then sealed and heated for $24 \mathrm{~h}$ at $100{ }^{\circ} \mathrm{C}$ under static conditions. The TEOS:P123:HCl: $\mathrm{H}_{2} \mathrm{O}: \mathrm{BuOH}: \mathrm{Cu}$ molar ratio in the synthesis gel mixture was 1:0.017:1.93:193:1.31:0.25. The final solid material was filtered off, washed several times with distilled water and dried at $100{ }^{\circ} \mathrm{C}$ for $6 \mathrm{~h}$. Calcination was carried out at 550 ${ }^{\circ} \mathrm{C}$ in air with a ramp rate of $2{ }^{\circ} \mathrm{C} / \mathrm{min}$ and an isothermal period of $6 \mathrm{~h}$ to obtain a template-free mesoporous catalyst. The samples are denoted herein as Cu-KIT- $6_{x}$, where $x$ indicates the $\mathrm{pH}$ value of the synthesis mixture. As a control, a Cu-KIT- 6 catalyst was prepared without $\mathrm{pH}$ adjustment, following the above procedure, and a cubic mesoporous KIT- 6 support was synthesized according to a standard procedure [10].

\subsection{Catalyst characterization}

The mesoporous structures and crystalline phases of the catalysts were characterized by X-ray powder diffraction (XRD) using a D8 Advance diffractometer (Bruker) fitted with a LynxEye detector. $\mathrm{Cu} K_{\alpha}$ radiation $(\lambda=0.154 \mathrm{~nm})$ was used and the X-ray tube was operated at $40 \mathrm{kV}$ and $40 \mathrm{~mA}$. The small-angle XRD patterns were acquired between $0.6^{\circ}$ and $3^{\circ}$ with a step width of $0.02^{\circ}$ at a count time of $0.4 \mathrm{~s}$ per step, and

Table 1

Dosage of $10 \mathrm{~mol} / \mathrm{L} \mathrm{NaOH}$ for the desired $\mathrm{pH}$ values.

\begin{tabular}{lcccccc}
\hline $\mathrm{V} / \mathrm{mL}$ & 4.5 & 4.8 & 4.9 & 5.2 & 5.5 & 6.0 \\
\hline $\mathrm{pH}$ & 1.43 & 2.27 & 3.78 & 3.97 & 4.24 & 6.62 \\
\hline
\end{tabular}


the wide-angle patterns were recorded from $15^{\circ}$ to $90^{\circ}$ with the same step width at a count time of $0.1 \mathrm{~s}$. Crystalline phases were assessed qualitatively via comparison with the Joint Committee on Power Diffraction Standards (JCPDS) database.

The textural properties of the catalysts (specific surface area, pore volume and average pore size) were determined by nitrogen physisorption studies conducted at $-196{ }^{\circ} \mathrm{C}$ using a Tristar II 3020 surface area and porosity analyzer (Micromeritics). Prior to $\mathrm{N}_{2}$ adsorption, approximately 110-120 mg samples were evacuated at $150{ }^{\circ} \mathrm{C}$ for $10 \mathrm{~h}$ to eliminate water and gaseous impurities on the sample surfaces. Total pore volumes were obtained by calculating the adsorbed volume at a relative pressure of 0.99 and specific surface areas were determined by the Brunauer-Emmett-Teller (BET) method over the relative pressure range of $0.05-0.3$. Pore size distributions were evaluated based on the adsorption branches of isotherms using the Barrett-Joyner-Halenda (BJH) method.

Surface morphologies were observed with a JEM-2100F (JEOL) transmission electron microscope (TEM) with a field emission gun operated at $200 \mathrm{kV}$. The calcined powder samples were first dispersed ultrasonically in ethanol and then drop-cast onto a 300-mesh copper grid.

Surface analyses and assessments of actual $\mathrm{Cu}$ contents of calcined catalysts were performed using X-ray photoelectron spectroscopy (XPS) and atomic absorption spectroscopy (AAS), respectively. XPS data were acquired with an ESCALAB instrument (Thermo) equipped with a monochromatized $\mathrm{Al} K \alpha \mathrm{X}$-ray source $(h v=1486.6 \mathrm{eV})$. The energy scale of the spectrometer was calibrated by setting the measured Si $2 p$ binding energy to $103.5 \mathrm{eV}$. Prior to AAS measurements, all samples were successively digested in $\mathrm{HF}$ and $\mathrm{HClO}_{4}$ solutions and were analyzed using a Z-2000 (Hitachi) graphite furnace atomic absorption spectrometer.

\subsection{Catalytic activity measurement}

Styrene epoxidation reactions over the $\mathrm{Cu}-\mathrm{KIT}-6_{x}$ catalysts were carried out at atmospheric pressure in a round-bottomed glass flask $(50 \mathrm{~mL})$ immersed in an oil bath and connected to a water-cooled reflux condenser. The reactant solution included $0.05 \mathrm{~g}$ of catalyst, $10 \mathrm{mmol}$ of styrene, $10 \mathrm{mmol}$ of TBHP and 10 $\mathrm{mL}$ of $\mathrm{CH}_{3} \mathrm{CN}$. A typical reaction was conducted at $70{ }^{\circ} \mathrm{C}$ for $6 \mathrm{~h}$ with continuous magnetic stirring. Following the reaction, the reactor was cooled to room temperature and a specific amount of toluene was added as an internal standard. The products in the liquid phase were analyzed quantitatively by gas chromatography (GC), using a Techcomp GC7900 equipped with a flame ionization detector and a 30-m TM-5 capillary column.

\section{Results and discussion}

\subsection{Characterization of catalysts}

\subsubsection{Bulk composition and physical properties of Cu-KIT-6x catalysts}

The low-angle XRD patterns indicate the crucial effects of the $\mathrm{pH}$ value on the structure of the mesophases (Fig. 1).
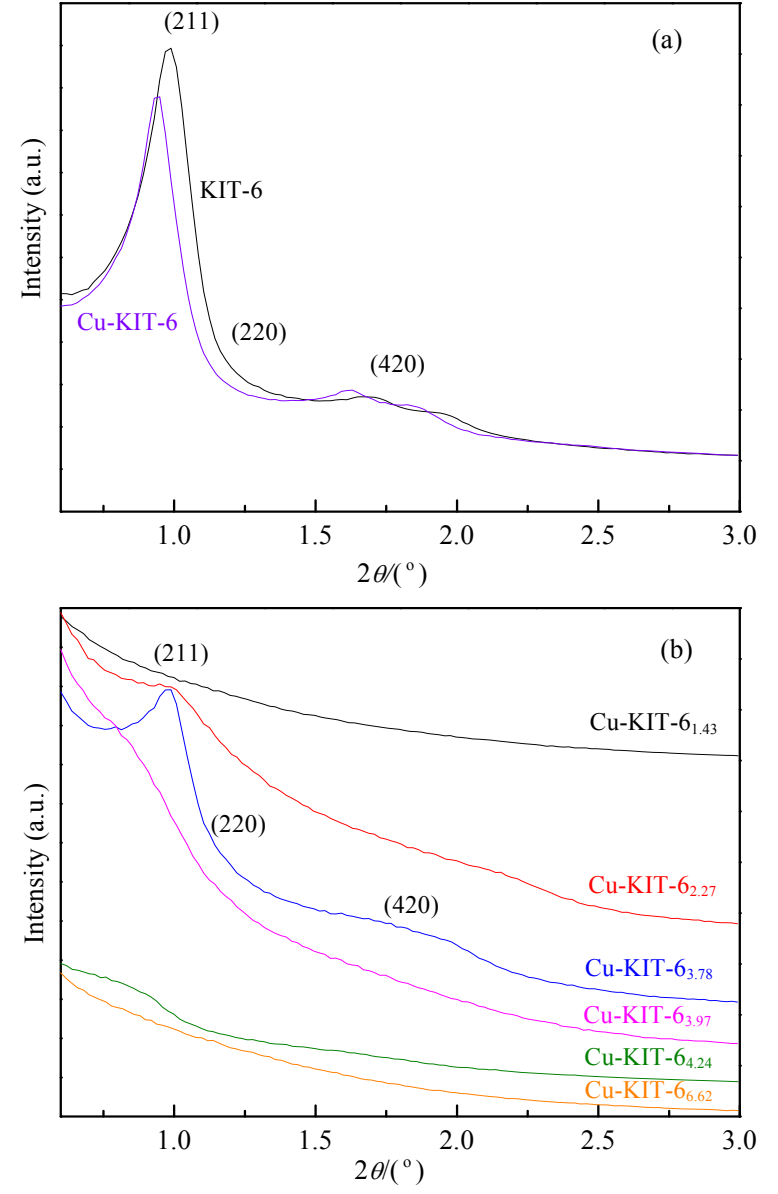

Fig. 1. Small-angle XRD patterns of different catalysts. (a) KIT-6; Cu-KIT-6; (b) Cu-KIT-6x.

Cu-KIT-6 synthesized without regulating the acidity generated well-resolved diffraction peaks at $2 \theta$ angles below $2^{\circ}$, corresponding to (211), (220) and (420) planes, respectively, and in good agreement with the XRD pattern of the parent KIT-6 (Fig. 1(a)). This result demonstrates that the Cu-KIT-6 had a typical structural order with a symmetry commensurate with the bicontinuous cubic Ia $3 d$ space group [10]. In Fig. 1(b), it can be seen that the $\mathrm{Cu}-\mathrm{KIT}-6_{2.27}$ and $\mathrm{Cu}-\mathrm{KIT}-6_{3.78}$ patterns display similar (211) diffraction peaks, indicating that the body-centered cubic mesoporous structure was retained to a certain degree. The overall decrease in the intensity of the diffraction lines may be a consequence of the reduction of scattering contrast between the channel wall of the silicate framework and the pore spaces, as this effect has been previously reported by several authors $[34,35]$. In contrast, other Cu-KIT- $6_{x}$ catalysts $(x$ $=1.43,3.97$ and 4.24 ) did not show well-ordered pore arrangements. It is likely that overly low or high amounts of $\mathrm{NaOH}$ could result in collapse of the cubic large mesopore structure. The continuous increase of the $\mathrm{pH}$ provides simpler thermodynamic control compared with the use of kinetic factors, thereby facilitating the flexible synthesis of mesoporous materials [36-38]. However, at $\mathrm{pH}$ values up to 6.62, the significant quantity of $\mathrm{NaOH}$ required to remove the silica template $[39,40]$ is also likely to significantly degrade the mesoporous silica, leading to a loss of structural regularity. As such, the fac- 
Table 2

Textural parameters of the calcined mesoporous Cu-KIT- $6_{x}$ materials.

\begin{tabular}{|c|c|c|c|c|c|c|}
\hline Catalyst & $\begin{array}{c}A_{\mathrm{BET}} \\
\left(\mathrm{m}^{2} / \mathrm{g}\right)\end{array}$ & $\begin{array}{c}\text { Pore } \\
\text { volume }^{a} \\
\left(\mathrm{~cm}^{3} / \mathrm{g}\right)\end{array}$ & $\begin{array}{l}\text { Pore } \\
\text { size } \\
(\mathrm{nm})\end{array}$ & $\begin{array}{l}d_{211^{\mathrm{b}}} \\
(\mathrm{nm})\end{array}$ & $\begin{array}{c}a_{0}{ }^{\mathrm{c}} \\
(\mathrm{nm})\end{array}$ & $\begin{array}{c}\text { Wall } \\
\text { thickness } \\
\text { (nm) }\end{array}$ \\
\hline KIT-6 & 676 & 1.17 & 6.1 & 8.93 & 21.9 & 4.9 \\
\hline Cu-KIT-6 & 676 & 1.09 & 5.7 & 9.31 & 22.8 & 5.7 \\
\hline Cu-KIT-61.43 & 439 & 0.45 & 3.8 & - & - & - \\
\hline $\mathrm{Cu}-\mathrm{KIT}-6_{2.27}$ & 655 & 0.62 & 3.9 & 9.20 & 22.5 & 7.4 \\
\hline Cu-KIT-63.78 & 657 & 0.86 & 5.0 & 8.94 & 21.9 & 6.0 \\
\hline Cu-KIT-63.97 & 576 & 1.11 & 7.0 & 10.73 & 26.3 & 6.1 \\
\hline Cu-KIT-64.24 & 400 & 1.14 & 9.8 & 10.91 & 26.7 & 3.6 \\
\hline Cu-KIT- $6_{6.62}$ & 277 & 0.93 & 10.9 & - & - & - \\
\hline
\end{tabular}

a Obtained from the adsorption branch.

${ }^{\mathrm{b}}$ Acquired from XRD patterns using Bragg's law.

c The unit cell parameter, $a_{0}=\sqrt{6} * d_{211}$.

${ }^{\mathrm{d}}$ Wall thickness $=1 / 2 a_{0}$ - pore size.

ile tailoring of the mesophase requires the use of an appropriate $\mathrm{pH}$ value. The main diffraction peaks of these materials were also shifted to lower $2 \theta$ values compared with those of pure KIT-6, implying that the lattice parameter $\left(d_{211}\right)$ and the corresponding unit cell parameter $\left(a_{0}\right)$ were both increased (Table 2). This is attributed to structural expansion caused by the larger size of $\mathrm{Cu}^{2+}$ ions (Pauling radius: $70 \mathrm{pm}$ ) compared with $\mathrm{Si}^{4+}$ ions (Pauling radius: $41 \mathrm{pm}$ ) [41-43]. These data provide evidence that $\mathrm{Cu}$ was partly incorporated into the framework of the KIT- 6 to replace $\mathrm{Si}^{4+}$ following the hydrothermal synthesis, such that $\mathrm{Cu}^{2+}$ ions were bonded with the silica matrix of KIT- 6 through bridging oxygen atoms. Shah et al. [44] proposed a possible pathway for the incorporation of $\mathrm{Cu}^{2+}$ ions into the framework of SBA-16. In this mechanism, the appropriate $\mathrm{pH}$ value allows $\mathrm{Cu}^{2+}$ in the interstitial regions between the silica-block copolymer to transition to the oxo form and condense with adjacent silanols, resulting in the introduction of metal atoms into the mesoporous walls.

The wide-angle XRD patterns of all samples were obtained from $15^{\circ}$ to $90^{\circ}$, as depicted in Fig. 2. Cu-KIT- $6_{x}$ generated a broad peak at $2 \theta=23^{\circ}$ that is attributed to amorphous features

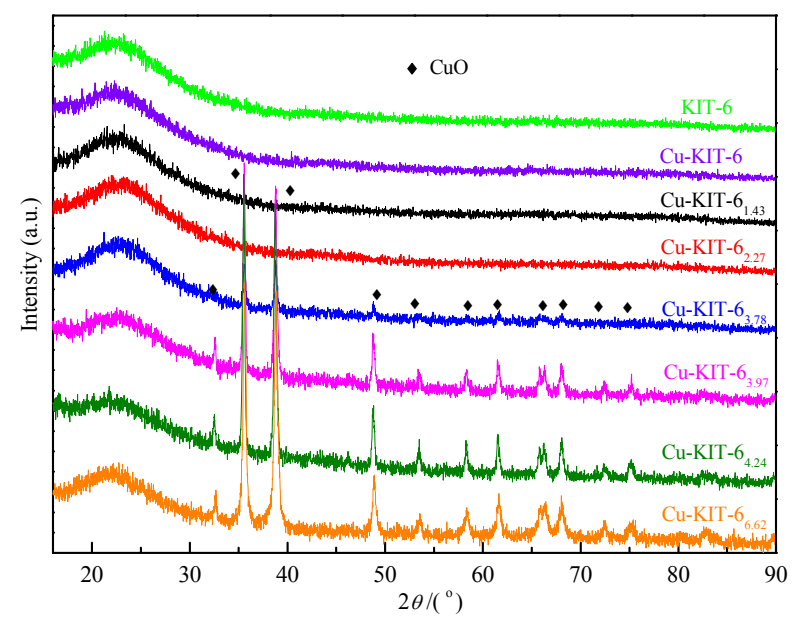

Fig. 2. Wide-angle XRD patterns of calcined KIT- 6 and Cu-KIT- $6_{x}$ catalysts.
Table 3

Elemental analyses analyzed by AAS for mesoporous Cu-KIT- $6 x$ materials.

\begin{tabular}{lc}
\hline Catalyst & Cu content (wt\%) \\
\hline Cu-KIT-6 & 0.000151 \\
Cu-KIT-61.43 & 0.169 \\
Cu-KIT-6.27 & 1.00 \\
Cu-KIT-6.78 & 4.57 \\
Cu-KIT-6.78 after 1st recycled test & 3.97 \\
Cu-KIT-6.6. & after 2nd recycled test \\
Cu-KIT-6.78 after 3rd recycled test & 3.82 \\
Cu-KIT-6.78 after 4th recycled test & 3.58 \\
Cu-KIT-6.97 & 3.33 \\
Cu-KIT-64.24 & 10.75 \\
Cu-KIT-6.62 & 13.25 \\
\hline
\end{tabular}

of $\mathrm{SiO}_{2}$. Characteristic copper oxide peaks were not observed at $x<3.78$. Interestingly, typical diffraction peaks for crystalline CuO with a monoclinic tenorite structure (JCPDS \#45-1548) [45] were produced at $\mathrm{pH}$ values over 3.78 , indicating that excessive amounts of $\mathrm{Cu}^{2+}$ had moved from the mesopores of the KIT- 6 to the external surface and gathered to form $\mathrm{CuO}$ clusters. It is also noteworthy that the peaks generated at Cu-KIT- $6_{x}$ for $x$ values above 3.78 were more intense than those of the $\mathrm{Cu}-\mathrm{KIT}-63.78$. This is proof that the amount of $\mathrm{CuO}$ anchored on the external surface gradually increased with $\mathrm{pH}$. In agreement with the XRD results in Fig. 2, the $\mathrm{Cu}$ content was found to be quite low at lower pH values (Table 3). The use of the appropriate $\mathrm{pH}$ thus has an important effect on the immobilization of $\mathrm{Cu}^{2+}$ on mesoporous KIT-6, and the subsequent incorporation of the metal into the mesophase channels. The bulk Cu concentrations were notably augmented with increases in the $\mathrm{pH}$. At a $\mathrm{pH}$ of 6.62 , the $\mathrm{Cu}$ level was close to the initial dosage (26.5\%). As demonstrated by the XRD data (Fig. 2), this large quantity of the metal was present in the form of $\mathrm{CuO}$ rather than $\mathrm{Cu}^{2+}$.

The gradual color change of these $\mathrm{Cu}$-containing catalysts also gave a clear indication of the bulk composition (Fig. 3). It is well known that bulk $\mathrm{CuO}$ is black [46], while the calcined $\mathrm{Cu}$-KIT-61.43 sample exhibited a white color similar to that of the parent KIT-6 support, suggesting that no bulk copper oxide existed. At $\mathrm{pH}=3.78$, the color was grey green, as a result of the

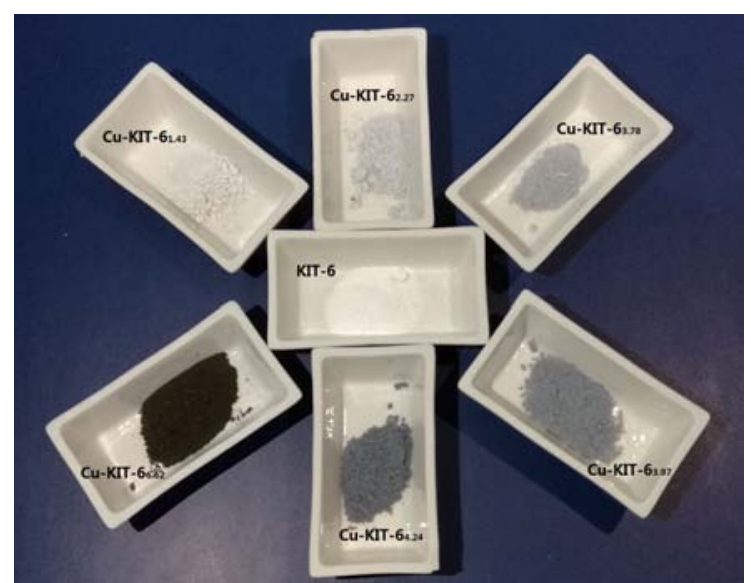

Fig. 3. Colors of calcined KIT-6 support and Cu-KIT-6x catalysts. 


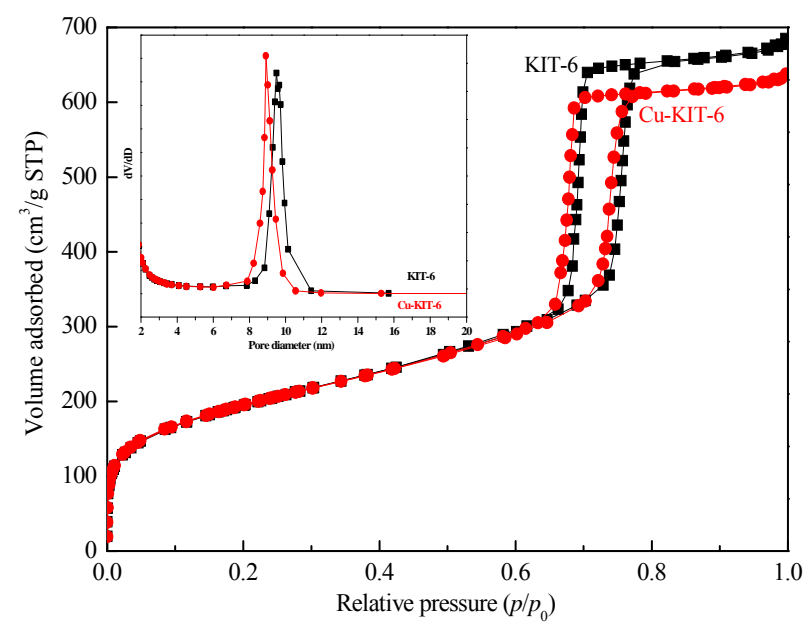

Fig. 4. $\mathrm{N}_{2}$ adsorption-desorption isotherms and respective $\mathrm{BJH}$ pore size distribution curves (inset) of KIT- 6 and Cu-KIT-6.

formation of -O-Si-0-Cu groups [47,48]. The grey color gradually became darker until $\mathrm{pH}=4.24$ and, at $\mathrm{pH}=6.62$, the calcined catalyst became very dark, suggesting the presence of copper oxide.

The textural parameters of the KIT- 6 and corresponding Cu-KIT- 6 materials were evaluated by nitrogen physisorption measurements. The $\mathrm{N}_{2}$ adsorption-desorption isotherm of KIT-6 (Fig. 4) displayed a type IV isotherm with an H1-type hysteresis loop in the relative pressure $\left(p / p_{0}\right)$ range of $0.6-0.8$, a typical indication of mesoporous materials with well-ordered cylindrical pores [49]. Well-defined and steep hysteresis loops with parallel adsorption-desorption branches indicated a narrow pore size distribution, in keeping with the inserted pore size distribution curves. The calcined KIT- 6 possessed a BET surface area of $676 \mathrm{~m}^{2} / \mathrm{g}$ and an average pore size of $6.1 \mathrm{~nm}$ (Table 2); these values are consistent with reported data [50]. After modification with $\mathrm{Cu}$ but without the addition of $\mathrm{NaOH}$, the $\mathrm{Cu}$-KIT- 6 exhibited a $\mathrm{N}_{2}$ adsorption isotherm, a BET surface area and an average pore size extremely close to those of the initial KIT-6. These results indicated that the ordered cubic mesoporous architecture was largely maintained and that little $\mathrm{Cu}^{2+}$ was incorporated into the KIT- 6 under highly acidic synthesis conditions ( $\mathrm{pH}=0.31$ in the initial KIT- 6 solution). This result is in agreement with previous reports that little $\mathrm{Al}^{3+}$ [51] or $\mathrm{Co}^{2+}$ [52] is introduced into the support in highly acidic SBA- 15 solutions.

It was also determined that there were no notable changes in the isotherms or in the shape of hysteresis loops for Cu-KIT- $6 x$ when $x$ was less than 4.24 (Fig. 5(a)). These isotherms showed almost identical mesopore structures. The sharpness of the adsorption branches of the isotherms also demonstrated uniformity of the mesopores in these samples. The evidence for empty cylindrical mesopores based on hysteresis at higher relative pressures $\left(p / p_{0}=0.5\right)$ confirmed that the pore structure of the support was preserved to some extent after $\mathrm{Cu}$ incorporation. Additionally, the slightly less steep slopes and lower inflections of the Cu-KIT- 61.43 and Cu-KIT- 62.27 isotherms reflected wider pore size distributions (Fig. 5(b)), as
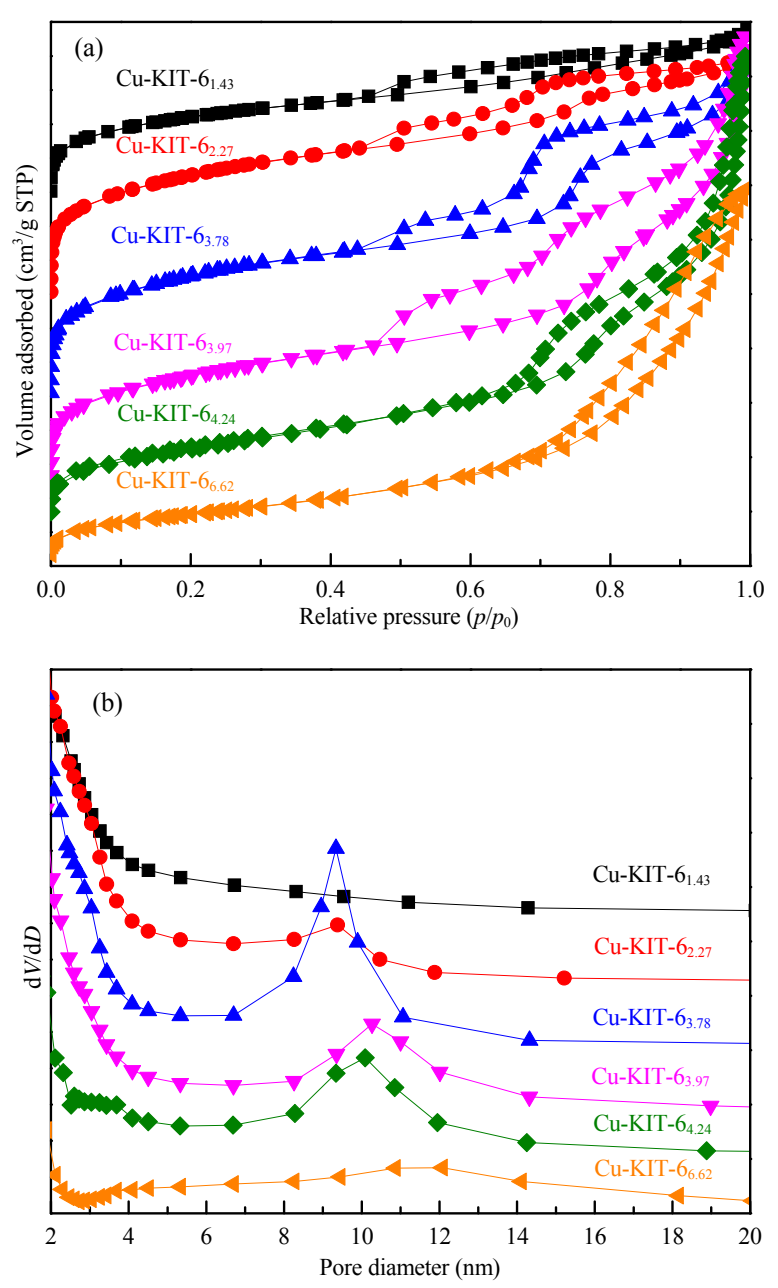

Fig. 5. $\mathrm{N}_{2}$ adsorption-desorption isotherms (a) and associated pore diameter distribution curves (b) of the calcined $\mathrm{Cu}-\mathrm{KIT}-6_{x}$ catalysts.

summarized in Table 2. Generally, the introduction of $\mathrm{Cu}$ was found to decrease the BET surface area. The pronounced decrease in the BET surface of the Cu-KIT- 61.43 is also attributed to the hydrolysis of the KIT- 6 mesopore structure as a result of the $\mathrm{pH}$ values applied, rather than solely being due to the incorporation of $\mathrm{Cu}$. The Cu-KIT-64.24 and Cu-KIT-66.62 displayed H3 hysteresis loops, a typical feature of slit pores [49], and the $p / p_{0}$ position of the inflection points of these isotherms were shifted to higher values, suggesting relatively wider pore size distributions (Fig. 5(b)). The increased pore size with $\mathrm{Cu}^{2+}$ incorporation could possibly be due to the longer $\mathrm{Cu}-\mathrm{O}$ bond length compared with $\mathrm{Si}-\mathrm{O}$. The degraded mesopore structures resulted in a minimal BET surface at a $\mathrm{pH}$ of 6.62. According to the geometrical model $[40,53,54]$, the wall thicknesses (Table 2) also changed with increasing $\mathrm{pH}$. It can therefore be stated that our synthesis method uniquely permits the systematic control of pore dimensions in ordered cubic Ia $3 d$ materials simply via $\mathrm{pH}$ adjustment with $\mathrm{NaOH}$. Moreover, among the fabricated $\mathrm{Cu}-\mathrm{KIT}-6_{x}$ materials, Cu-KIT-63.78 exhibited a higher BET surface area, a similar pore size to that of KIT- 6 and effective $\mathrm{Cu}$ loading, all of which would be expected to significantly promote the conversion of styrene during epoxidation. 


\subsubsection{Morphological properties of Cu-KIT- $6_{x}$ catalysts}

TEM provided crucial evidence for the presence of ordered mesoporous architectures in the KIT-6 support (Fig. 6) and corresponding Cu-KIT- $6_{x}$ materials (Fig. 7). KIT-6 displayed an ordered array of hexagonal mesopores over a wide range (Fig. 6(A)). The inset image obtained via fast Fourier transform (FFT) highlights the interconnectivity in the pore structure of the cubic $I a 3 d$ silica, a finding that is consistent with reports in the literature [10]. In addition, regular strip-like channels are observed in the side-view (Fig. 6(B)), and the silica walls are parallel to one another. The pore size obtained from TEM images was $6.6 \mathrm{~nm}$, slightly lower than those previously reported [50]. These results are indicative of a high quality ordered mesoporous silica.

The TEM images clearly show the dependence of the channel order of the Cu-KIT- $6_{x}$ materials on the pH value (Fig. 7). Without $\mathrm{pH}$ adjustment, the Cu-KIT-6 (Fig. 7(A)) presented a pore structure similar to that of the parent KIT-6, owing to the minimal amount of $\mathrm{Cu}$ introduced into the silica skeleton (Table 3). Fig. 7(B) shows disordered cubic Ia3d mesopores, which is consistent with the small-angle XRD analysis and pore diameter distribution. This result demonstrates that the Ia3d construction collapsed at $\mathrm{pH}=1.43$. In Fig. $7(\mathrm{C})$ and (D), the pores exhibit various shapes, such as square grid, hexagonal, distorted hexagonal and linear, due to the different viewing directions $[55,56]$. These well-regulated pore arrangements confirm the preservation of the host structure after modification with $\mathrm{Cu}$ via the $\mathrm{pH}$-adjustment method. It is noteworthy that a perfectly resolved cubic diffraction pattern analogous to that of pristine KIT-6 is observed in the inserted FFT image in Fig. 7(D). This result demonstrates the coherence of these domains. The moderate introduction of $\mathrm{Cu}$ atoms at an appropriate $\mathrm{pH}$ therefore had a minimal effect on the cubic mesoporous framework of the KIT-6. It should also be noted that at a pH of 3.78, approximately $4.6 \mathrm{wt} \% \mathrm{Cu}$ (Table 3) was introduced into the silica without distorting the pore array. The pore size determined from Fig. 7(D) is $5.7 \mathrm{~nm}$, which is approximately

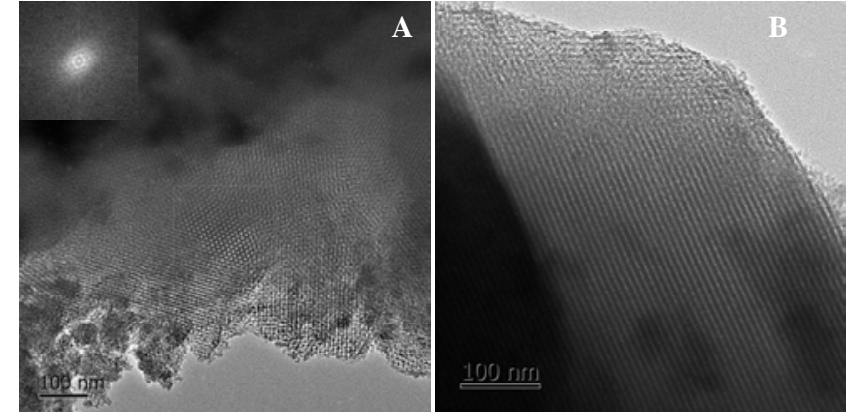

Fig. 6. TEM images of KIT- 6 fabricated under aging temperature of 100 ${ }^{\circ} \mathrm{C}$. Image viewed in the direction parallel to the pore axis (A, fast Fourier transform (FFT) inset) and image viewed in the direction perpendicular to the pore axis (B).

equal to that calculated from $\mathrm{N}_{2}$ adsorption-desorption data. Excessive $\mathrm{NaOH}$ evidently led to reduced symmetry, as seen in Fig. 7(E) and (F). At the highest pH value (Fig. 7(G)), the symmetry of the mesopore structure suffered significant degradation, with a sizeable decrease in the BET surface area and many mesopore defects, as is also evident from the $\mathrm{N}_{2}$ adsorption-desorption isotherms (Fig. 5). Fig. 7(E-G) show the appearance of black spots, indicative of the agglomeration of metal oxides on the surface of the support as a result of the excessive incorporation of $\mathrm{Cu}$. This effect was also observed in the large-angle XRD patterns (Fig. 2). Moreover, these black spots gradually increased with the addition of $\mathrm{NaOH}$, highlighting the augmentation of the $\mathrm{Cu}$ content, as indicated in Table 3.

\subsubsection{Surface properties of Cu-KIT- $6_{x}$ catalysts}

To further clarify the states of surface $\mathrm{Cu}$ species, $\mathrm{Cu} 2 p$ XPS spectra were acquired. Neither Cu-KIT-6 nor Cu-KIT-61.43 generated a $\mathrm{Cu}$ peak, owing to the lower levels of $\mathrm{Cu}$ in these materials (data not shown). The other catalysts exhibited two primary peaks centered at 935 and $954 \mathrm{eV}$ (Fig. 8), attributable to the characteristic spin-orbit splitting of $\mathrm{Cu}^{2+}$ into $2 p_{3 / 2}$ and $2 p_{1 / 2}$ peaks $[57,58]$. The distinct shake-up satellite peak at
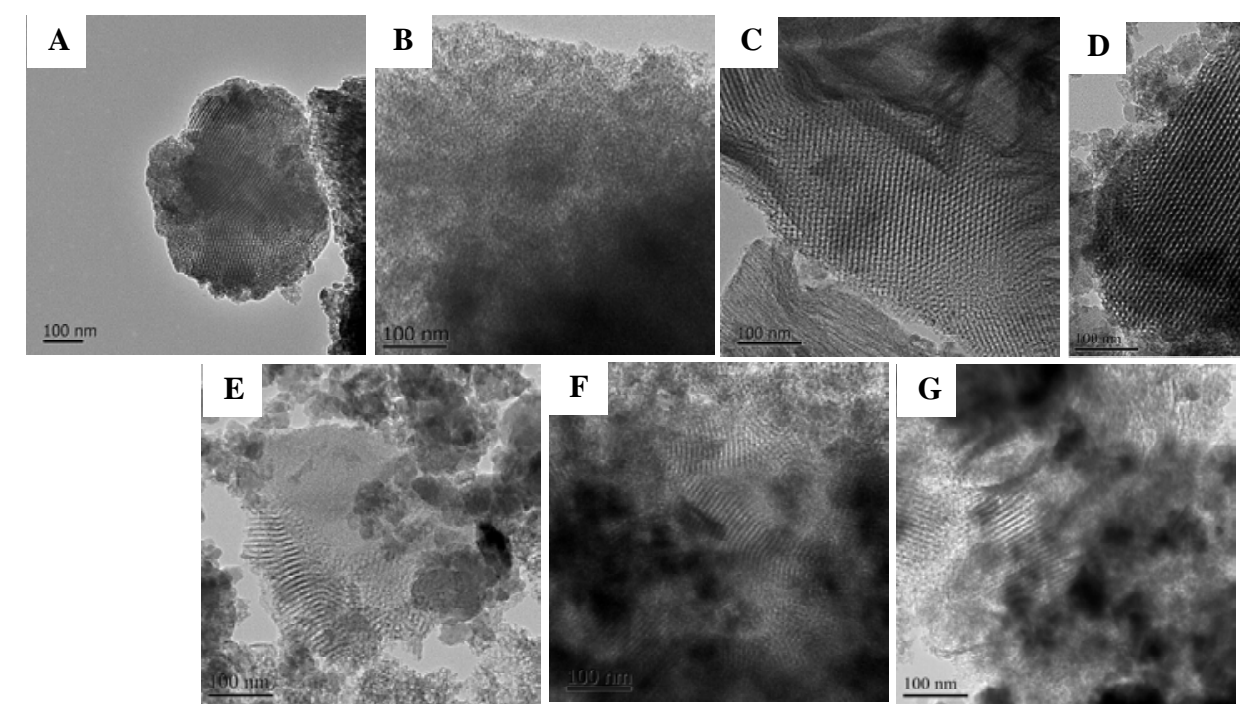

Fig. 7. TEM images of the Cu-KIT-6x at various pH values. (A) Cu-KIT-6; (B) Cu-KIT-61.43; (C) Cu-KIT-62.27; (D) Cu-KIT-63.78; (E) Cu-KIT-6 ( $_{3.97}$; (F) Cu-KIT-64.24; (G) Cu-KIT-6 6.62 . The fast Fourier transform (FFT) diagram was inserted. 


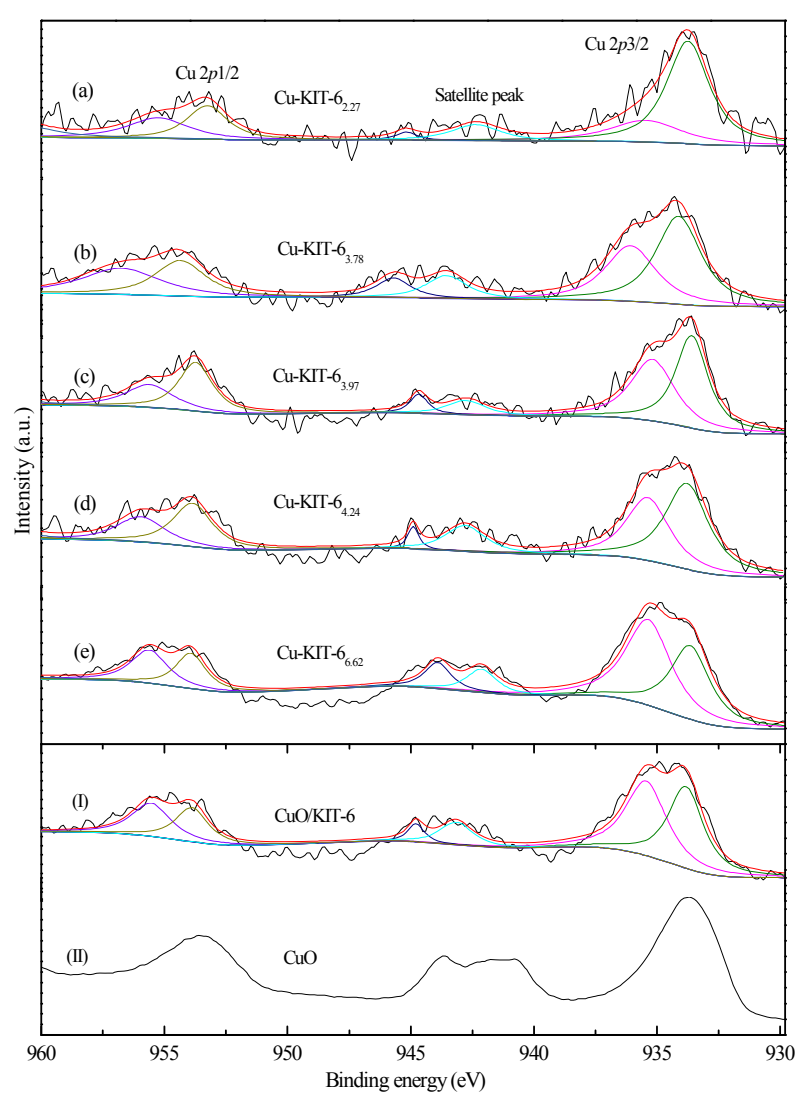

Fig. 8. XPS spectra of $\mathrm{Cu} 2 p$ core level for Cu-KIT- $6_{x}$ catalysts.

$943.0 \mathrm{eV}$, approximately $10 \mathrm{eV}$ higher than the $\mathrm{Cu} 2 p_{3 / 2}$ excitation position, confirms the presence of $\mathrm{Cu}^{2+}$ with an open $3 d^{9}$ structure instead of $\mathrm{Cu}^{+}$or metallic $\mathrm{Cu}$ species with filled $d$ levels [59-61].

The electron binding energy levels of certain elements depend not only on oxidation state but in most cases also on the chemical environment. The differing peak asymmetries of these $\mathrm{Cu} 2 p_{3 / 2}$ core level peaks reveal the presence of different $\mathrm{Cu}$ species. The chemical environment of each species was assessed by subsequent deconvolution of each $\mathrm{Cu} 2 p$ peak into two doublets, using the XPS peak41 software package. All catalysts generated a peak at $933.7 \mathrm{eV}$, in accordance with that of standard bulk CuO (profile II) [62-64], providing evidence for the complete decomposition of the copper nitrate upon calcination. Cu-KIT- 6 adjusted to high pH values (profiles (c)-(e)) exhibited another contribution at higher binding energy values of 935.1-935.4 eV, similar to the results obtained with CuO/KIT-6 prepared by the impregnation method (profile I). This peak can assigned to dispersed $\mathrm{CuO}$ and to intimate interactions between $\mathrm{CuO}$ and the mesoporous silica matrix $[65,66]$. In contrast to the above catalysts, Cu-KIT- 6 prepared at moderate $\mathrm{pH}$ values of 2.27 and 3.78 (profiles (a) and (b)) showed a distinct peak at a binding energy of $936.0 \mathrm{eV}$, indicative of the presence of -O-Si-O-Cu linkages in the matrix $[66,67]$. Compared with Cu-KIT-62.27 (profile (a)), the much more intense peak located at $936.0 \mathrm{eV}$ in the Cu-KIT-63.78 data (profile (b)) demonstrate that the majority of copper species incorporated into the silica matrix were present in the form of $-\mathrm{O}-\mathrm{Si}-\mathrm{O}-\mathrm{Cu}$.

\subsection{Catalytic properties during the epoxidation of styrene}

Preliminary investigations of the reaction parameters over the $\mathrm{Cu}-\mathrm{KIT}-6_{3.78}$ catalyst showed that styrene conversion and selectivity for SO both increased with reaction temperature $\left(50-80{ }^{\circ} \mathrm{C}\right)$ and reaction time $(2-10 \mathrm{~h})$ (Table 4). However, reaction temperatures higher than $70{ }^{\circ} \mathrm{C}$ and reaction times longer than $6 \mathrm{~h}$ did not significantly improve the catalytic performance. Additionally, compared with TBHP, $\mathrm{H}_{2} \mathrm{O}_{2}$ was found to be an ineffective oxidant for converting styrene, giving a fairly low styrene conversion (3\%).

A series of Cu-KIT- $6_{x}$ mesoporous materials was evaluated for the epoxidation of styrene using TBHP as the oxidation agent under optimized reaction conditions (Table 5). The pure KIT-6 support showed poor performance, similar to that obtained from a blank trial, confirming that KIT- 6 without active metal sites is inactive for styrene epoxidation. After the incorporation of $\mathrm{Cu}$ species, a slight enhancement in styrene conversion and SO yields from the Cu-KIT-6 and Cu-KIT-61.43 were observed. These results show the predominant role played by $\mathrm{Cu}^{2+}$ in the catalytic performance. The conversion of the substrate and the SO yield continually improved with increases in the $\mathrm{Cu}^{2+}$ concentration up to $\mathrm{pH}=3.78$. The highest conversion of $43.5 \%$, in conjunction with an SO selectivity of $86.6 \%$, was obtained over the Cu-KIT-63.78. In addition to SO, benzaldehyde (selectivity 13.4\%) was also detected. Cu-KIT-63.78, which possessed a higher BET surface area and a larger pore volume analogous to that of the parent KIT-6 (Table 2), exhibited minimal pore blockage and so provided a convenient route for reactant diffusion into the mesopores, leading to excellent catalytic activity $[68,69]$. However, although the $\mathrm{Cu}$ content increased when $x$ surpassed 3.78 (Table 3), the conversion and corresponding SO yields exhibited the opposite trend, indicating that the $\mathrm{Cu}$ loading was not the only factor contributing to the conversion of styrene. Specifically, the Cu-KIT-66.62 catalyst with a $\mathrm{Cu}$ content 3.5 -fold (17 wt\%) higher than that of the Cu-KIT-63.78 (4.6 wt\%) (Table 3) only gave moderate catalytic performance. This is believed to have occurred because the increased concentration of $\mathrm{Cu}$ species resulted in extra-framework $\mathrm{CuO}$ clusters (Figs. 2 and $7(\mathrm{G})$ ) that covered

Table 4

Effect of reaction parameters on the epoxidation of styrene over Cu-KIT-63.78 catalyst.

\begin{tabular}{lcccc}
\hline Reaction & $\begin{array}{c}\text { Reaction time } \\
\text { temperature }\left({ }^{\circ} \mathrm{C}\right)\end{array}$ & $\begin{array}{c}\text { Conversion } \\
(\%)\end{array}$ & \multicolumn{2}{c}{ Selectivity (\%) } \\
\cline { 3 - 5 } & 6 & 14.0 & 56.5 & 43.5 \\
50 & 6 & 28.0 & 75.3 & 24.7 \\
70 & 6 & 43.5 & 86.6 & 13.4 \\
70 & 6 & 42.2 & 88.9 & 11.1 \\
70 & 6 & 3.0 & 28.3 & 71.7 \\
70 b & 2 & 28.3 & 88.0 & 12.0 \\
70 & 4 & 44.7 & 88.7 & 11.3 \\
70 & 8 & 45.0 & 84.2 & 15.8 \\
70 & 10 & 51.6 & 85.3 & 14.7 \\
70 & 10 & & \\
\hline
\end{tabular}

Reaction conditions: styrene $10 \mathrm{mmol}$, TBHP $10 \mathrm{mmol}$, acetonitrile 10 $\mathrm{mL}$.

a SO and BA refer to styrene oxide and benzaldehyde, respectively.

${ }^{\mathrm{b}}$ Hydrogen peroxide (aqueous solution $30 \mathrm{wt} \%$ ) was used as oxidant. 
Table 5

Performance of various prepared catalysts for epoxidation of styrene.

\begin{tabular}{|c|c|c|c|c|c|c|}
\hline \multirow{2}{*}{ Catalyst } & \multirow{2}{*}{ Solvent } & \multirow{2}{*}{$\begin{array}{c}\text { Conversion } \\
(\%)\end{array}$} & \multicolumn{2}{|c|}{ Selectivity (\%) } & \multirow{2}{*}{$\begin{array}{c}\text { SO yield }{ }^{\mathrm{b}} \\
(\%)\end{array}$} & \multirow{2}{*}{$\begin{array}{l}\text { TOF }^{\mathrm{c}} \\
\left(\mathrm{h}^{-1}\right)\end{array}$} \\
\hline & & & $\mathrm{SO}^{\mathrm{a}}$ & $\mathrm{BA}^{\mathrm{a}}$ & & \\
\hline Blank & $\mathrm{CH}_{3} \mathrm{CN}$ & 18.3 & 80.7 & 19.3 & 14.8 & - \\
\hline KIT-6 & $\mathrm{CH}_{3} \mathrm{CN}$ & 17.3 & 82.0 & 18.0 & 14.2 & - \\
\hline $\mathrm{Cu}-\mathrm{KIT}-6$ & $\mathrm{CH}_{3} \mathrm{CN}$ & 19.0 & 78.3 & 21.7 & 14.9 & - \\
\hline $\mathrm{Cu}-\mathrm{KIT}-6_{1.43}$ & $\mathrm{CH}_{3} \mathrm{CN}$ & 20.7 & 81.0 & 19.0 & 16.8 & 267.2 \\
\hline Cu-KIT-6 2.27 & $\mathrm{CH}_{3} \mathrm{CN}$ & 26.3 & 77.0 & 23.0 & 20.3 & 57.4 \\
\hline Cu-KIT-63.78 & $\mathrm{CH}_{3} \mathrm{CN}$ & 43.5 & 86.6 & 13.4 & 37.7 & 20.5 \\
\hline $\mathrm{Cu}-\mathrm{KIT}-6_{3.78}$ & DMF & 9.0 & 75.3 & 24.7 & 6.8 & 4.3 \\
\hline Cu-KIT-63.78 & pyridine & 21.0 & 66.3 & 33.7 & 13.9 & 10.0 \\
\hline Cu-KIT-63.78 & tert-butanol & 3.7 & 2.3 & 97.7 & 0.09 & 1.8 \\
\hline Cu-KIT-63.78 & 1,4-dioxane & 12.3 & 74.0 & 26.0 & 9.1 & 5.9 \\
\hline Cu-KIT-63.97 & $\mathrm{CH}_{3} \mathrm{CN}$ & 36.3 & 84.7 & 15.3 & 30.7 & 7.4 \\
\hline $\mathrm{Cu}-\mathrm{KIT}-6_{4.24}$ & $\mathrm{CH}_{3} \mathrm{CN}$ & 35.0 & 84.3 & 15.7 & 29.5 & 5.8 \\
\hline $\mathrm{Cu}-\mathrm{KIT}-6_{6.62}$ & $\mathrm{CH}_{3} \mathrm{CN}$ & 34.0 & 88.0 & 12.0 & 29.9 & 4.4 \\
\hline
\end{tabular}

Reaction conditions: styrene $10 \mathrm{mmol}$, TBHP $10 \mathrm{mmol}$, acetonitrile 10 $\mathrm{mL}, 70^{\circ} \mathrm{C}, 6 \mathrm{~h}$.

asO and BA refer to styrene oxide and benzaldehyde, respectively.

b Moles of synthesized styrene epoxide/moles of supplied styrene.

${ }^{c}$ Moles of converted styrene/moles of copper per hour.

some of the active $\mathrm{Cu}$ sites and blocked the pore interiors, thus hampering access to the active catalytic sites. The losses in activity along with the augmentation of the $\mathrm{Cu}$ content inevitably led to a dramatic decline in the turnover frequency (TOF). The catalytic performance tests also demonstrated that the performance was correlated with the concentration of -O-Si-O-Cu groups in the catalyst. Therefore, this $\mathrm{Cu}$ arrangement in the framework might represent active sites for the epoxidation of styrene. Other similar studies have found that incorporating $\mathrm{Co}^{2+}[70]$ or $\mathrm{Fe}^{3+}$ [71] species into the silica framework generates activity for oxidation reactions. Similarly, Selvaraj et al. [72] reported that isolated $\mathrm{Ce}^{4+}$ in the framework of SBA-15 led to high performance during the liquid phase oxidation of cyclohexane with hydrogen peroxide. This was attributed to the generation of a large number of Lewis acid sites that enhanced the catalytic activity.

Generally, the nature of the solvent (such as protic or aprotic, low or high dielectric constant) has an important effect on the yields and product distributions [73-75]. In the present study, different solvents, including protic (tert-butanol) and aprotic $\left(\mathrm{CH}_{3} \mathrm{CN}\right.$, dimethylformanide (DMF), pyridine and 1,4-dioxane), were employed to catalyze the epoxidation of styrene using TBHP (Table 5). The results showed that styrene conversion varied significantly depending on the nature of the solvent: the aprotic solvents favored the oxidation reaction, whereas in the protic solvent the reaction was slower. Using tert-butanol as the solvent, the reaction showed the lowest conversion, along with benzaldehyde as the main product. These results can be explained by the high steric hindrance and low electrophilicity of the solvent $[76,77]$. Under the identical reaction conditions, the styrene conversion and epoxidation selectivity were both improved in conjunction with increasing polarity of the aprotic solvents (as indicated by their dielectric constants). The Cu-KIT-63.78 exhibited excellent catalytic behavior in terms of reactivity and SO selectivity in polar aprotic
$\mathrm{CH}_{3} \mathrm{CN}$, which can be reasonably attributed to the higher dielectric constant of this solvent (36.6) [78]. Dramatic declines in SO selectivity in pyridine and 1,4-dioxane solutions were related to their lower dielectric constants $(13.3$, and 2.22 , respectively). Based on previous reports, this effect occurs because the higher dielectric constant and strong polarity of $\mathrm{CH}_{3} \mathrm{CN}$ lead to higher concentrations of the substrate over the catalyst surface and also increase the solubility of the substrate and oxidant [79-81]. Based on these effects, the oxidant and substrate are able to readily reach the active sites of the catalyst $[82,83]$. Nevertheless, one exception was found; although DMF has a dielectric constant of 38.3 (similar to that of $\mathrm{CH}_{3} \mathrm{CN}$ ), it yielded poor reaction performance, with only $9.0 \%$ styrene conversion. Previous studies have reported that DMF is the best solvent for styrene oxidation, especially when oxygen is used as the oxidant and cobalt species as catalysts [84-86]. This is because DMF has two effects in the reaction: an affinity for oxygen [87] and coordination with cobalt to form active sites [70].

A representative catalyst, $\mathrm{Cu}-\mathrm{KIT}-6_{3.78}$, was found to exhibit excellent recyclability and stability in four consecutive runs (Fig. 9). Following each reaction $\left(6 \mathrm{~h}, 70^{\circ} \mathrm{C}\right)$, the catalyst was
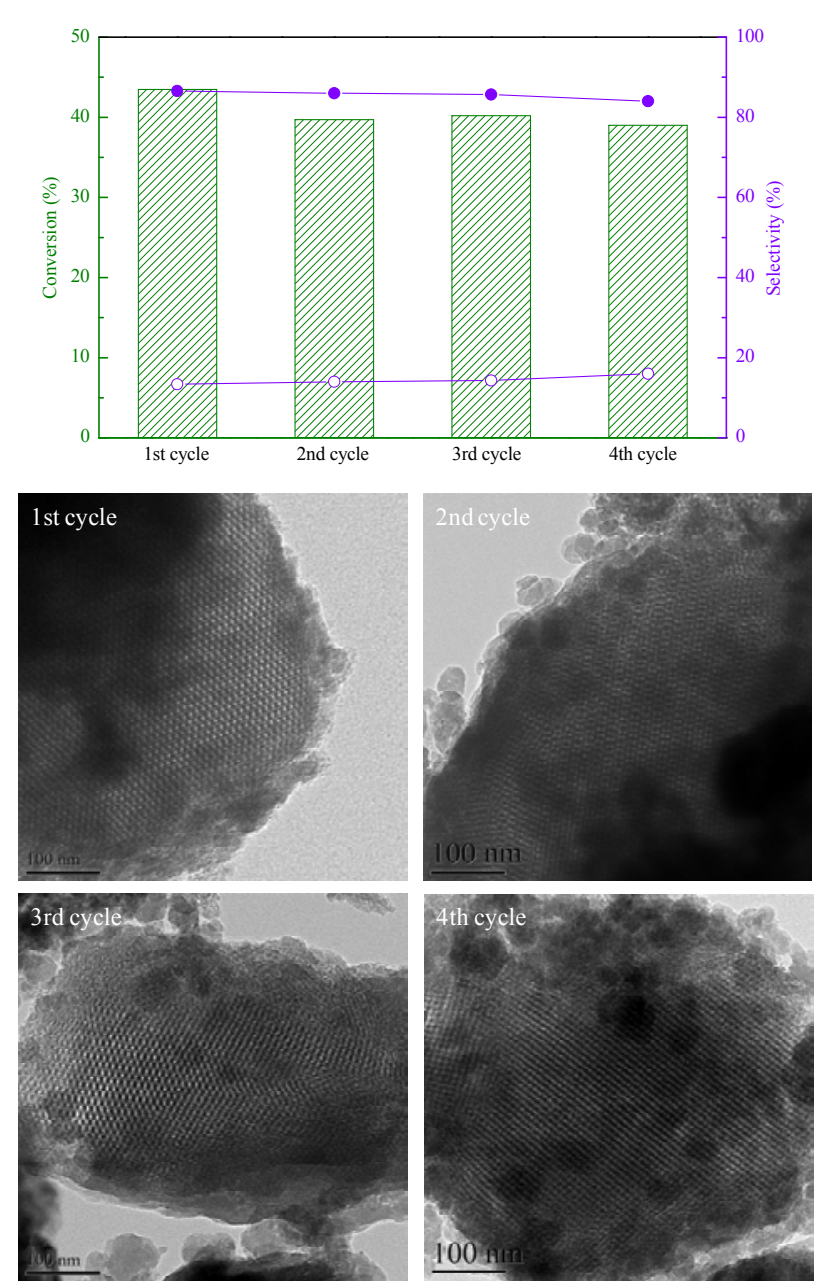

Fig. 9. The catalytic results and TEM images in various runs on Cu-KIT-63.78 recycling for epoxidation of styrene. Symbols: styrene conversion (bar), selectivities to styrene epoxide $(\bullet)$ and benzaldehyde $(0)$. Reaction conditions: styrene $10 \mathrm{mmol}$, TBHP $10 \mathrm{mmol}$, acetonitrile 10 $\mathrm{mL}, 70^{\circ} \mathrm{C}, 6 \mathrm{~h}$. 
separated from the liquid phase by filtration, thoroughly washed with ethanol and dried at $60{ }^{\circ} \mathrm{C}$ for $12 \mathrm{~h}$ to regenerate it. During four trials, the conversions of styrene and the selectivity for SO showed slight oscillations within the ranges of $40 \%-44 \%$ and $84 \%-87 \%$, respectively, demonstrating very good reusability. Additionally, after each cycle, the Cu-KIT-63.78 maintained a well-ordered cubic Ia3d mesoporous architecture (Fig. 9) analogous to that of the fresh catalyst (Fig. 7(D)), confirming its structural stability. AAS analyses showed that the catalyst was highly resistant to leaching, with no significant loss of its $\mathrm{Cu}$ content (Table 3). Considering the aforementioned characterization results, $\mathrm{Cu}^{2+}$ in the form of $-\mathrm{O}-\mathrm{Si}-\mathrm{O}-\mathrm{Cu}$ groups among the mesoporous silica lattice evidently formed a constant $\mathrm{Cu}$ reservoir and this improved the stability of the catalytic behavior.

Compared with other studies based on $\mathrm{Cu}$ catalysts for olefin epoxidation, the selectivity for SO over the Cu-KIT-63.78 was superior and this material also appears to be easy to use and convenient to separate following the reaction. Several researchers have focused on anchoring $\mathrm{Cu}^{2+}$ on amine-functionalized mesoporous silica, and most of these compounds have shown selectivities towards SO of less than $70 \%$, with unexceptional conversions even after lengthy reaction times [88,89]. As an example, $\mathrm{Cu}(\mathrm{II})$ acetylacetonate on a core-shell structured $\mathrm{Fe}_{3} \mathrm{O}_{4} @ \mathrm{SiO}_{2}$ presented a styrene conversion of $86.7 \%$ and SO selectivity of $51.4 \%$, while requiring a rather complicated preparation process [90]. Cu-phthalocyanine catalysts exhibited 50\% styrene conversion during epoxidation, although this required three times the usual amount of TBHP over $24 \mathrm{~h}$, demonstrating a lower utilization rate for the oxidant [91]. Analogously, Cu-doped hydrotalcites exhibited mediocre styrene conversion even at high dosages of TBHP [92]. In conclusion, the $\mathrm{Cu}$-KIT-63.78 catalyst obtained via $\mathrm{pH}$-adjustment may have potential applications to the catalytic epoxidation of styrene.

\section{Conclusions}

Cu-containing mesoporous KIT-6 materials synthesized via $\mathrm{pH}$-adjustment exhibited the formation of different morpholo- gies, mesopore structures and physical properties. At the optimal pH of 3.78, approximately $4.6 \% \mathrm{Cu}^{2+}$ was inserted into the silica support, the majority of which formed $\mathrm{Cu}-\mathrm{O}-\mathrm{Si}-\mathrm{O}$ structures in the matrix without destroying the structural integrity of the cubic Ia3d mesophase. However, a high $\mathrm{pH}$ over 3.78 resulted in a less-ordered structure with particle agglomeration, and excessive $\mathrm{Cu}^{2+}$ was primarily dispersed on the surface of the KIT- 6 support as $\mathrm{CuO}$. It is evident that the $\mathrm{pH}$ of the initial gel can greatly affect the activity of the material for styrene epoxidation. Cu-KIT-63.78, which had the highest BET surface area and exhibited an ordered mesoporous construction, was the highest performing catalyst, and gave a styrene conversion of $43.5 \%$ and SO selectivity of $86.6 \%$. These findings reveal that the structural order of mesoporous materials is an important factor in achieving enhanced styrene epoxidation. This $\mathrm{pH}$ adjustment method is expected to allow structural control and channel modification during the fabrication of 3D ordered mesoporous materials.

\section{References}

[1] B. S. Lane, K. Burgess, Chem. Rev., 2003, 103, 2457-2473.

[2] K. Sato, M. Aoki, M. Ogawa, T. Hashimoto, R. Noyori, J. Org. Chem., 1996, 61, 8310-8311.

[3] G. Grigoropoulou, J. H. Clark, J. A. Elings, Green Chem., 2003, 5, 1-7.

[4] G. Chatel, C. Goux-Henry, A. Mirabaud, T. Rossi, N. Kardos, B. Andrioletti, M. Draye, J. Catal., 2012, 291, 127-132.

[5] X. H. Lu, Q. H. Xia, H. J. Zhan, H. X. Yuan, C. P. Ye, K. X. Su, G. Xu, J. Mol. Catal. A, 2006, 250, 62-69.

[6] M. Mirzaee, B. Bahramian, M. Mirebrahimi, Chin. J. Catal., 2016, 37, 1263-1274.

[7] D. Zhou, B. Tang, X. H. Lu, X. L. Wei, K. Li, Q. H. Xia, Catal. Commun., 2014, 45, 124-128.

[8] G. Yang, X. Chen, X. L. Wang, W. H. Xing, N. P. Xu, Chin. J. Catal., 2013, 34, 1326-1332.

[9] S. J. Datta, K. B. Yoon, Chin. J. Catal., 2015, 36, 897-905.

[10] F. Kleitz, S. H. Choi, R. Ryoo, Chem. Commun., 2003, 2136-2137.

[11] K. Flodstrom, V. Alfredsson, N. Kallrot, J. Am. Chem. Soc., 2003, 125, 4402-4403.

[12] B. R. Jermy, S. Y. Kim, K. V. Bineesh, M. Selvaraj, S. K. Song, J. W. Ryu, D. W. Park, Korean J. Chem. Eng., 2009, 26, 1241-1245.

[13] R. Merkache, I. Fechete, M. Maamache, M. Bernard, P. Turek, K.

\section{Graphical Abstract}

Chin. J. Catal., 2017, 38: 518-528 doi: 10.1016/S1872-2067(17)62767-0

\section{One-pot synthesis of ordered mesoporous Cu-KIT- 6 and its improved catalytic behavior for the epoxidation of styrene: Effects of the pH value of the initial gel}

Baitao Li*, Xin Luo, Jing Huang, Xiujun Wang, Zhenxing Liang* South China University of Technology

Using a synthesis solution at a pH of 3.78 , approximately $4.6 \% \mathrm{Cu}^{2+}$ was incorporated into the framework of a KIT- 6 support in the form of $-\mathrm{Cu}-\mathrm{O}-\mathrm{Si}$ groups. Enhanced selectivity for styrene oxide was obtained over this Cu-KIT-63.78 catalyst.

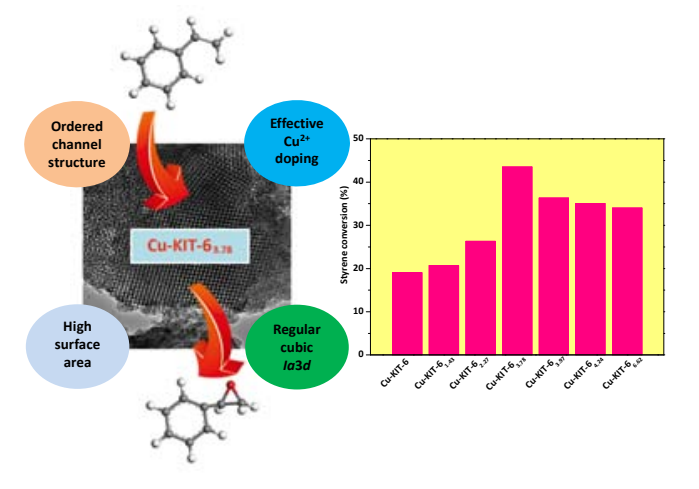


Al-Dalama, F. Garin, Appl. Catal. A, 2015, 504, 672-681.

[14] S. Aslam, F. Subhan, Z. Yan, W. Xing, J. Zeng, Y. Liu, M. Ikram, S. Rehman, R. Ullah, Microporous Mesoporous Mater., 2015, 214, 54-63.

[15] M. Hussain, P. Akhter, G. Saracco, N. Russo, Appl. Catal. B, 2015, 170-171, 53-65.

[16] B. L. Newalkar, J. Olanrewaju, S. Komarneni, Chem. Mater., 2001, 13, 552-557.

[17] Y. F. Shao, L. Z. Wang, J. L. Zhang, M. Anpo, J. Phys. Chem. B, 2005, 109, 20835-20841.

[18] B. T. Li, S. Y. Zhang, Int. J. Hydrogen Energy, 2013, 38, 14250-14260.

[19] J. A. Melero, L. F. Bautista, J. Iglesias, G. Morales, R. Sánchez-Vázquez, Catal. Today, 2012, 195, 44-53.

[20] S. Wu, Y. Han, Y. C. Zou, J. W. Song, L. Zhao, Y. Di, S. Z. Liu, F. S. Xiao, Chem. Mater., 2004, 16, 486-492.

[21] Y. Li, Y. J. Guan, R. A. van Santen, P. J. Kooyman, I. Dugulan, C. Li, E. J. M. Hensen, J. Phys. Chem. C, 2009, 113, 21831-21839.

[22] R. Van Grieken, J. M. Escola, J. Moreno, R. Rodríguez, Chem. Eng. J., 2009, 155, 442-450.

[23] M. Selvaraj, Y. Choe, Appl. Catal. A, 2010, 373, 186-191.

[24] X. D. Zhang, Z. P. Qu, X. Y. Li, Q. D. Zhao, X. Zhang, X. Quan, Mater. Lett., 2011, 65, 1892-1895.

[25] Y. Wang, G. H. Chen, F. M. Zhang, L. Q. Li, Res. Chem. Intermed., 2013, 40, 385-397.

[26] C. Anand, S. Joseph, G. Lawrence, D. S. Dhawale, M. A. Wahab, J. H. Choy, A. Vinu, ChemCatChem, 2013, 5, 1863-1870.

[27] M. U. Anu Prathap, B. Kaur, R. Srivastava, J. Colloid Interface Sci., 2012, 381, 143-151.

[28] W. C. Zhan, Y. L. Guo, Y. Q. Wang, Y. Guo, G. Z. Lu, J. Rare Earth., 2010, 28, 369-375.

[29] X. J. Jin, X. Y. Qian, B. T. Li, J. Nanosci. Nanotechnol., 2014, 14, 7234-7241.

[30] H. C. Gao, Y. Yan, X. H. Xu, J. H. Yu, H. L. Niu, W. X. Gao, W. X. Zhang, M. J. Jia, Chin. J. Catal., 2015, 36, 1811-1817.

[31] M. Lashanizadegan, F. Mousavi, React. Kinet. Mech. Catal., 2015, 116, 421-431.

[32] V. R. Choudhary, R. Jha, N. K. Chaudhari, P. Jana, Catal. Commun., 2007, 8, 1556-1560.

[33] C. Q. Chen, J. Qu, C. Y. Cao, F. Niu, W. G. Song, J. Mater. Chem., 2011, 21, 5774-5779.

[34] J. Sauer, F. Marlow, F. Schüth, Phys. Chem. Chem. Phys., 2001, 3, 5579-5584.

[35] Y. Yin, P. Tan, X. Q. Liu, J. Zhu, L. B. Sun, J. Mater. Chem. A, 2014, 2, 3399-3406.

[36] M. Choi, W. Heo, F. Kleitz, R. Ryoo, Chem. Commun., 2003, 1340-1341.

[37] F. Kleitz, D. Liu, G. M. Anilkumar, I. S. Park, L. A. Solovyov, A. N. Shmakov, R. Ryoo, J. Phys. Chem. B, 2003, 107, 14296-14300.

[38] F. Kleitz, L. A. Solovyov, G. M. Anilkumar, S. H. Choi, R. Ryoo, Chem. Commun., 2004, 1536-1537.

[39] T. Grewe, X. Deng, C. Weidenthaler, F. Schüth, H. Tüysüz, Chem. Mater., 2013, 25, 4926-4935.

[40] A. Rumplecker, F. Kleitz, E. L. Salabas, F. Schüth, Chem. Mater., 2007, 19, 485-496.

[41] H. L. Zhang, C. J. Tang, Y. Y. Lv, C. Z. Sun, F. Gao, L. Dong, Y. Chen, J. Colloid Interface Sci., 2012, 380, 16-24.

[42] L. P. Wang, A. G. Kong, B. Chen, H. M. Ding, Y. K. Shan, M. Y. He, J. Mol. Catal. A, 2005, 230, 143-150.

[43] Y. L. Dong, X. Y. Niu, Y. J. Zhu, F. L. Yuan, H. G. Fu, Catal. Lett., 2011, 141, 242-250.

[44] A. T. Shah, B. Li, S. A. Nagra, Can. J. Chem. Eng., 2011, 89,
1288-1295.

[45] T. Tsoncheva, G. Issa, J. M. López Nieto, T. Blasco, P. Concepcion, M. Dimitrov, G. Atanasova, D. Kovacheva, Microporous Mesoporous Mater., 2013, 180, 156-161.

[46] D. P. Strommen, K. Nakamoto, Appl. Spectrosc., 1983, 37, 436-439.

[47] C. F. Zhou, Y. M. Wang, Y. Cao, T. T. Zhuang, W. Huang, Y. Chun, J. H. Zhu, J. Mater. Chem., 2006, 16, 1520-1528.

[48] P. Gaudin, S. Dorge, H. Nouali, M. Vierling, E. Fiani, M. Molière, J.-F. Brilhac, J. Patarin, Appl. Catal. B, 2016, 181, 379-388.

[49] K. S. W. Sing, Pure Appl. Chem., 1982, 54, 2201-2218.

[50] H. Tüysüz, C. W. Lehmann, H. Bongard, B. Tesche, R. Schmidt, F. Schüth, J. Am. Chem. Soc., 2008, 130, 11510-11517.

[51] A. Ungureanu, B. Dragoi, V. Hulea, T. Cacciaguerra, D. Meloni, V. Solinas, E. Dumitriu, Microporous Mesoporous Mater., 2012, 163, 51-64.

[52] B. T. Li, Y. R. Zhu, X. J. Jin, J. Solid State Chem., 2015, 221, 230-239.

[53] L. A. Solovyov, V. I. Zaikovskii, A. N. Shmakov, O. V. Belousov, R. Ryoo, J. Phys. Chem. B, 2002, 106, 12198-12202.

[54] T. W. Kim, L. A. Solovyov, J. Mater. Chem., 2006, 16, 1445-1455.

[55] V. Alfredsson, M. W. Anderson, Chem. Mater., 1996, 8, 1141-1146.

[56] D. Kumar, K. T. Pillai, V. Sudersanan, G. K. Dey, N. M. Gupta, Chem. Mater., 2003, 15, 3859-3865.

[57] M. P. Pachamuthu, V. V. Srinivasan, R. Maheswari, K. Shanthi, A. Ramanathan, Catal. Sci. Technol., 2013, 3, 3335-3342.

[58] A. Narani, R. K. Marella, P. Ramudu, K. S. Rama Rao, D. R. Burri, RSC Adv., 2014, 4, 3774-3781.

[59] J. Janas, J. Gurgul, R. P. Socha, S. Dzwigaj, Appl. Catal. B, 2009, 91, 217-224.

[60] J. Zhou, Q. H. Xia, S. C. Shen, S. Kawi, K. Hidajat, J. Catal., 2004, 225, 128-137.

[61] C. M. Chanquí, K. Sapag, E. Rodríguez-Castellón, E. R. Herrero, G. A. Eimer, J. Phys. Chem. C, 2010, 114, 1481-1490.

[62] A. Corma, A. Palomares, F. Márquez, J. Catal., 1997, 170, 132-139.

[63] W. L. Dai, Q. Sun, J. F. Deng, D. Wu, Y. H. Sun, Appl. Surf. Sci., 2001, 177, 172-179.

[64] W. Grünert, N. W. Hayes, R. W. Joyner, E. S. Shpiro, M. R. H. Siddiqui, G. N. Baevas, J. Phys. Chem., 1994, 98, 10832-10846.

[65] J. P. Espinós, J. Morales, A. Barranco, A. Caballero, J. P. Holgado, A. R. Gonzalez-Elipe, J. Phys. Chem. B, 2002, 106, 6921-6929.

[66] Z. Y. Wu, Y. M. Wang, W. W. Huang, J. Yang, H. J. Wang, J. H. Xu, Y. L. Wei, J. H. Zhu, Chem. Mater., 2007, 19, 1613-1625.

[67] S. Bennici, A. Gervasini, N. Ravasio, F. Zaccheria, J. Phys. Chem. B, 2003, 107, 5168-5176.

[68] J. Sun, Q. B. Kan, Z. F. Li, G. L. Yu, H. Liu, X. Y. Yang, Q. S. Huo, J. Q. Guan, RSC Adv., 2014, 4, 2310-2317.

[69] B. T. Li, X. Luo, Y. R. Zhu, X. J. Wang, Appl. Surf. Sci., 2015, 359, 609-620.

[70] Q. H. Tang, Q. H. Zhang, H. L. Wu, Y. Wang, J. Catal., 2005, 230, 384-397.

[71] Y. Wang, Q. H. Zhang, T. Shishido, K. Takehira, J. Catal., 2002, 209, 186-196.

[72] M. Selvaraj, D. W. Park, C. S. Ha, Microporous Mesoporous Mater., 2011, 138, 94-101.

[73] F. Wang, C. Liu, G. Liu, J. H. Liu, J. Porous Mater., 2015, 22, 1423-1430.

[74] J. H. Noh, R. Patala, R. Meijboom, Appl. Catal. A, 2016, 514, 253-266.

[75] M. Selvaraj, S. W. Song, S. Kawi, Microporous Mesoporous Mater., 2008, 110, 472-479.

[76] V. Hulea, E. Dumitriu, Appl. Catal. A, 2004, 277, 99-106.

[77] Y. Yang, S. J. Hao, P. P. Qiu, F. P. Shang, W. L. Ding, Q. B. Kan, React. Kinet. Mech. Catal., 2010, 100, 363-375. 
[78] J. A. Dean, Lange's Handbook of Chemistry, 15th ed., McGraw-Hill, New York, 1999, 1-1292.

[79] C. Saux, L. B. Pierella, Appl. Catal. A, 2011, 400, 117-121.

[80] S. M. Islam, A. Singha Roy, P. Mondal, S. Mondal, M. Mubarak, D. Hossain, S. Sarkar, J. Appl. Polym. Sci., 2011, 120, 2743-2753.

[81] L. B. Pierella, C. Saux, S. C. Caglieri, H. R. Bertorello, P. G. Bercoff, Appl. Catal. A, 2008, 347, 55-61.

[82] B. T. Li, X. J. Jin, Y. R. Zhu, L. Chen, Z. J. Zhang, X. J. Wang, Inorg. Chim. Acta, 2014, 419, 66-72.

[83] Y. J. Guo, Z. W. Liu, G. J. Wang, Y. H. Huang, F. F. Kang, Appl. Surf. Sci., 2011, 258, 1082-1090.

[84] X. H. Lu, Q. H. Xia, D. Zhou, S. Y. Fang, A. L. Chen, Y. L. Dong, Catal. Commun., 2009, 11, 106-109.

[85] H. J. Zhan, Q. H. Xia, X. H. Lu, Q. Zhang, H. X. Yuan, K. X. Su, X. T. Ma,
Catal. Commun., 2007, 8, 1472-1478.

[86] H. T. Cui, Y. Zhang, Z. G. Qiu, L. F. Zhao, Y. L. Zhu, Appl. Catal. B, 2010, 101, 45-53.

[87] X. H. Lu, Q. H. Xia, S. Y. Fang, B. Xie, B. Qi, Z. R. Tang, Catal. Lett., 2009, 131, 517-525.

[88] K. Parida, K. G. Mishra, S. K. Dash, Ind. Eng. Chem. Res., 2012, 51, 2235-2246.

[89] S. Jana, S. Bhunia, B. Dutta, S. Koner, Appl. Catal. A, 2011, 392, 225-232.

[90] J. Sun, G. L. Yu, L. L. Liu, Z. F. Li, Q. B. Kan, Q. S. Huo, J. Q. Guan, Catal. Sci. Technol., 2014, 4, 1246-1252.

[91] J. Manna, A. J. Amali, R. K. Rana, Chem. Eur. J., 2014, 20, 8453-8457.

[92] N. T. Thao, L. T. K. Huyen, Chem. Eng. J., 2015, 279, 840-850.

\title{
含铜有序介孔Cu-KIT-6的合成及其苯乙烯环氧化催化性能：pH值的影响
}

\author{
李白滔”, 罗 歆, 黄 静, 王秀军, 梁振兴 ${ }^{*}$ \\ 华南理工大学化学与化工学院, 广东省燃料电池技术重点实验室, 广东广州510640
}

\begin{abstract}
摘要: 苯乙烯侧链 $\mathrm{C}=\mathrm{C}$ 的选择性氧化一直是烯烃环氧化研究领域关注的热点之一. 近几十年来, 苯乙烯环氧化研究主要集 中于多相过渡金属催化剂的开发与应用; 以铜为主要活性物种的催化剂因具有较高的环氧苯乙烷选择性而备受瞩目. 然 而, 采用 $\mathrm{pH}$ 调节法将铜离子引入三维六方介孔材料KIT-6阵列尚未见报道, 尤其是 $\mathrm{pH}$ 值对合成材料的形貌、结构以及催化 活性的影响尚未可知. 基于此, 本文采用 $\mathrm{pH}$ 调节法合成了铜嵌入KIT-6介孔材料Cu-KIT- $6 x$ ( $x$ 代表初始溶胶的 $\mathrm{pH}$ 值, $x=$ $1.43,2.27,3.78,3.97,4.24,6.62)$, 并将其应用于苯乙烯环氧化反应. 采用X射线粉末衍射、氮气吸附脱附、透射电子显微镜 以及X射线光电子能谱等手段对Cu-KIT-6x的表面结构及形貌进行了细致表征.

结果表明, 随着 $\mathrm{pH}$ 的变化, Cu-KIT-6x催化剂的物理特性、表面结构尤其是铜物种种类和含量均变化较大. 较低的 $\mathrm{pH}$ 导 致铜物种主要以 $\mathrm{Cu}^{2+}$ 形式存在, 难以引入到KIT-6骨架中, 且不利于介孔材料的合成, 最终导致产生无序介孔结构. 当 $\mathrm{pH}$ 增 大到 3.78 时, 约有 $4.6 \mathrm{wt} \%$ 的 $\mathrm{Cu}(\mathrm{II})$ 以- $\mathrm{Cu}-\mathrm{O}-\mathrm{Si}-$ 形式成功引入KIT-6骨架中, 获得了具有较高比表面积且有序的孔结构. 此 外, 由于 $\mathrm{Cu}^{2+}$ 的引入, 骨架内部分 $\mathrm{Si}^{4+}$ 被取代, 促使Cu-KIT-6 3 .78 拥有可与载体KIT-6相媲美的大孔径. 然而, 当 $\mathrm{pH}$ 继续增大时, 过量的 $\mathrm{Cu}^{2+}$ 从KIT-6骨架中析出, 以 $\mathrm{CuO}$ 形式存在于载体表面, 从而导致Cu-KIT-6的孔径逐渐增大; 同时 $\mathrm{NaOH}$ 对三维立方 介孔结构的破坏, 使得介孔结构坍塌及比表面积显著降低.

以苯乙烯环氧化反应评价了 Cu-KIT-6x系列催化剂的催化活性. 当以叔丁基过氧化氢为氧化剂, 乙腈为溶剂, 在 $70^{\circ} \mathrm{C} 反$ 应6 h 后, Cu-KIT- $6_{3.78}$ 表现出最优的苯乙烯转化率 $(43.5 \%$ )及环氧苯乙烷选择性(86.6\%). 使用4次后, Cu-KIT-6 3.78 展示了稳定 的苯乙烯转化率、环氧苯乙烷选择性及有序的孔结构, 充分表明其具有出色的稳定性. 各表征结果揭示了在适宜 $\mathrm{pH}$ 下合成 的Cu-KIT- $6_{3.78}$ 催化剂具有较高的铜含量、有序的立方I $a 3 d$ 介孔结构及合适的结构参数, 因而在苯乙烯环氧化反应中表现优 异活性和良好稳定性.
\end{abstract}

关键词: 介孔材料; KIT-6; 苯乙烯环氧化; pH调节

收稿日期: 2016-11-12. 接受日期: 2016-12-20. 出版日期: 2017-03-05.

*通讯联系人. 电话/传真: (020)87112943; 电子信箱: btli@scut.edu.cn

井通讯联系人. 电话/传真: (020)87113584; 电子信箱: zliang@scut.edu.cn

基金来源：广东省科技计划(2015A020216002); 广东省自然科学基金(2014A030313259); 国家自然科学基金(21543014, 21173086, U1301245).

本文的英文电子版由Elsevier出版社在ScienceDirect上出版(http://www.sciencedirect.com/science/journal/18722067). 